\title{
Opção Decolonial e Práxis Curriculares de Enfrentamento do Racismo: diálogos com sujeitos curriculantes de licenciaturas da Universidade da Integração Internacional da Lusofonia Afro-Brasileira
}

\author{
FERREIRA, Michele Guerreiro ${ }^{1}$ \\ SILVA, Janssen Felipe $d a^{2}$
}

\section{RESUMO}

Baseado no Pensamento Decolonial (QUIJANO, 2005, 2007; GROSFOGUEL, 2008, 2016; MIGNOLO, 2005, 2011; MALDONADO-TORRES, 2007, 2016; WALSH, 2008), apresentamos resultados da pesquisa de Doutorado em Educação (UFPE), ao buscarmos elementos de práxis decolonizadora e de enfrentamento do racismo nas práticas curriculares em cursos de formação de professoras/es. O campo da pesquisa foi a UNILAB dado o seu peculiar perfil político e epistêmico de integração e de ponte para diálogos Sul-Sul. Utilizamos a Análise de Conteúdo (BARDIN, 2011; VALA, 1990) para analisar os dados coletados/produzidos nas entrevistas não-diretivas (GUBER, 2001). O objetivo deste artigo é analisar elementos de enfrentamento do racismo presentes nas práticas curriculares apontadas pelos diversos sujeitos curriculantes a partir de suas concepções de racismo que indicam opções teórico-práticas adotadas na direção de enfrentar e superar o racismo, tanto biológico quanto epistêmico.

\author{
Educação das Relações Étnico-Raciais. Currículo. Racismo. Racismo \\ Epistêmico. Práxis Decolonizadora.
}

Decolonial Option and Curricular Praxis against Racism: dialogues with curriculum relatable subjects majoring in education in the University for International Integration of the Afro-Brazilian Lusophony

\footnotetext{
${ }^{1}$ Doutora em Educação pelo Núcleo de Pesquisa de Formação de Professores e Prática Pedagógica - UFPE. Professora de História da rede estadual de ensino de Pernambuco; Integrante do Instituto de Estudos da América Latina (IAL-UFPE); Associada da ABPN (Associação Brasileira de Pesquisadoras/es Negras/os), da ANPED (Associação Nacional de Pós-Graduação e Pesquisa em Educação - GT 21: Educação e Relações Étnico-Raciais) e da ALAS (Associação Latino-Americana de Sociologia); Integrante do NUPEFEC (Núcleo de Pesquisa, Extensão e Formação em Educação do Campo) CAA/UFPE e do Grupo de Estudo Pós-Coloniais e Teoria da Complexidade em Educação CAA/UFPE. E-mail: mguerreirof@hotmail.com.

2 Doutor em Educação pelo Núcleo de Pesquisa de Formação de Professores e Prática Pedagógica - UFPE. Professor Associado II do Centro Acadêmico do Agreste no Núcleo de Formação Docente - UFPE e Professor Permanente dos Programas de Pós-Graduação em Educação do Centro de Educação e do Centro Acadêmico do Agreste da UFPE. Coordenador do Grupo de Estudos Pós-Coloniais e Teoria da Complexidade na Educação (CAA/UFPE). Vice-líder do Laboratório de Estudos Antropológicos e Coordenador do Instituto de Estudos de América Latina - IAL/UFPE. E-mail: janssenfelipe@hotmail.com.
} 
Opção Decolonial e Práxis Curriculares de Enfrentamento do Racismo: diálogos com sujeitos curriculantes de licenciaturas da Universidade da Integração Internacional da

\section{ABSTRACT}

Based on Decolonial Thinking (QUIJANO, 2005, 2007; GROSFOGUEL, 2008, 2016; MIGNOLO, 2005, 2011; MALDONADO-TORRES, 2007, 2016; WALSH, 2008), we present results of the doctorate degree research in Education (UFPE), in which we seek elements of decolonizing praxis and confronting racism in curricular practices in teacher training courses. The research developed in UNILAB given its peculiar political and epistemic profile of integration and bridge to South-South dialogues. We used Content Analysis (BARDIN, 2011; VALA, 1990) to analyze data collected / produced in nondirective interviews (GUBER, 2001). The objective of this article is to show elements of confrontation of racism present in the curricular practices pointed out by the various curriculum subjects from their conceptions of racism that indicate the theoretical-practical options adopted in the direction of facing and overcoming racism, both biological and epistemic.

Ethnic-Racial Relations Education. Curriculum. Racism. Epistemic Racism. Decolonizing Praxis.

\section{INTRODUÇÃO}

Este artigo é fruto da pesquisa de Doutorado em Educação intitulada: Educação das Relações Étnico-Raciais e Prática Curricular de Enfrentamento do Racismo na UNILAB desenvolvida no Programa de PósGraduação em Educação na linha de pesquisa Formação de Professores e Práticas Pedagógicas da Universidade Federal de Pernambuco, sob a orientação do professor Dr. Janssen Felipe da Silva.

O objetivo do presente artigo é apresentar resultados obtidos na referida pesquisa ao buscarmos elementos de práxis decolonizadora e de enfrentamento do racismo nos currículos de cursos de formação de professoras/es da Universidade da Integração Internacional da Lusofonia AfroBrasileira - UNILAB. Com base nesses resultados analisamos as práticas curriculares apontadas pelos diversos sujeitos curriculantes (docentes e discentes) que indicam opções teórico-práticas adotadas no sentido de enfrentar e superar o racismo, tanto biológico quanto epistêmico.

A lente teórica adotada para desenvolver tal intento é o Pensamento Decolonial (QUIJANO, 2005, 2007; GROSFOGUEL, 2008, 2016; MIGNOLO, 2005, 2011; MALDONADO-TORRES, 2007, 2016; WALSH, 2008). Destacamos que as chaves conceituais trazidas por estas/es autoras/es nos ajudam a compreender as implicações da racionalidade eurocêntrica em relação à construção sócio-histórica da raça e do racismo, do conhecimento científico moderno e de seus efeitos sobre o currículo. Neste artigo, decidimos mobilizar seus conceitos ao longo do texto, explicando-os, caso seja necessário, sem 
Opção Decolonial e Práxis Curriculares de Enfrentamento do Racismo: diálogos com sujeitos curriculantes de licenciaturas da Universidade da Integração Internacional da Lusofonia Afro-Brasileira

abrir uma seção específica para tratá-los como o fizemos em trabalhos anteriores ${ }^{3}$.

Adotamos a Análise de Conteúdo (BARDIN, 2011; VALA, 1990), a qual de acordo com Vala (Ibid.) leva-nos, através da inferência, a ultrapassar o limite da mera descrição, conduzindo-nos à interpretação através da atribuição de sentidos dada às características do objeto que foram criteriosamente levantadas e organizadas. É por esta razão que para analisarmos os dados coletados/produzidos a partir do Diário de Campo e das entrevistas não diretivas (GUBER, 2001), adotamos a Análise de Conteúdo Temática (BARDIN, Ibid.), que se propõe a construir os núcleos ou indicadores de sentidos que partem das categorias teóricas, ou seja, da abordagem teórica que precisamos nos apropriar para fazer as inferências.

Este artigo está organizado em quatro seções: a) apresentação da importância da UNILAB como campo para a realização da pesquisa e apresentação das licenciaturas estudadas; b) apresentação dos sujeitos da pesquisa enquanto sujeitos curriculantes (MACEDO, 2013), ou seja, autores autorizados a pensar e a praticar os currículos das licenciaturas em pauta; c) análise das concepções de racismo dos sujeitos curriculantes e; d) as considerações finais, que apontam as contribuições para a decolonização dos currículos de formação de professoras/es.

\section{A Criação da UNILAB e os Desafios que Transpassam a Integração e a Interculturalidade}

Nesta seção, situamos a criação e implementação da Universidade da Integração Internacional da Lusofonia Afro-Brasileira situando sua importância dentro do contexto histórico, político e social da conformação da educação das relações étnico-raciais no Brasil, destacando seu caráter integrador e de cooperação internacional, especialmente com a África. Também elencamos os principais desafios encontrados em nossa pesquisa diante de sua implementação.

As universidades de integração internacional apresentam elementos de interculturalidade, mas guardam suas especificidades. Catherine Walsh (2010) apresenta um levantamento a respeito das leis publicadas no cenário de constituição de um sistema de educação voltado para a educação das relações étnico-raciais que a autora chama de Intercultural. Walsh destaca o México como primeiro país a instituir um modelo educativo desde a educação primária até a universidade que privilegie a interculturalidade. Esse novo modelo foi instituído em 2001 e contou com a criação de universidades interculturais a partir de 2003. Walsh, no entanto, chama a atenção para um detalhe: as referidas universidades foram pensadas para abordar temas indígenas para

\footnotetext{
${ }^{3}$ Ver Ferreira e Silva 2015, 2018.
} 
Opção Decolonial e Práxis Curriculares de Enfrentamento do Racismo: diálogos com sujeitos curriculantes de licenciaturas da Universidade da Integração Internacional da Lusofonia Afro-Brasileira indígenas, daí a autora questiona: por que nomear, então, tais universidades como "interculturais" e não como universidades indígenas?

O questionamento da autora é fundado no reconhecimento de que a educação intercultural é para todos, assim, a efetivação de sua proposta não deveria se limitar a relacionar a diversidade linguística e cultural, sem promover o processo de estudo e aprendizagem inter-epistêmico como nos mostra a seguir:

Pero tal vez el mejor ejemplo de su esfuerzo de
"interculturalizar", tiene relación con los saberes y
conocimientos. Al reconocer que la ciencia y el conocimiento
no son singulares y únicos, e identificar los conocimientos
ancestrales como conocimientos científicos y tecnológicos,
relevantes y necesarios para todos. (WALSH, 2010, p. 87).

A Bolívia (a partir de 2008) e o Equador (a partir de 2009), segundo a autora, avançam em relação à perspectiva mexicana por considerar em suas políticas educacionais o reconhecimento do próprio Estado como plurinacional elevando a tentativa de interculturalidade ao campo epistêmico. A preocupação com o que conta como conhecimento tem a ver com a questão do privilégio epistêmico que leva a uma forma de racismo quando se estabelece uma hierarquia entre os conhecimentos ou ainda quando não se relaciona com os anseios e as necessidades reais da sociedade.

Considerando as diferenças culturais e étnico-raciais brasileiras podemos destacar iniciativas de educação intercultural para povos indígenas ${ }^{4}$, assim como o propósito de ampliar o acesso ao ensino superior, por meio de uma política de expansão que prevê dois movimentos importantes: o da interiorização, abrindo campi universitários no interior dos estados, desconcentrando a oferta de vagas das capitais das unidades federativas, e o movimento da internacionalização, seja por meio de bolsas de estudos no exterior, seja por meio da criação de universidades de integração internacional (como é o caso da UNILA e da UNILAB).

As universidades de integração internacional não trazem em sua constituição a condição de se autodeclararem interculturais, como foi o caso do México, por exemplo, mas, no caso específico da UNILAB, esta foi concebida para promover:

a cooperação internacional solidária com os países de Língua Oficial Portuguesa. A instituição tem como premissa considerar o perfil local e regional, de profundas desigualdades sociais e econômicas, apontadas pelos indicadores da região Nordeste do Brasil e do Maciço de Baturité. Destaca-se, nesse sentido, a importância da educação, como elemento de indução de um processo de desenvolvimento sustentável. Ao fomentar a

\footnotetext{
${ }^{4}$ Ver Eliene Amorim de Almeida (2017).
} 
Opção Decolonial e Práxis Curriculares de Enfrentamento do Racismo: diálogos com sujeitos curriculantes de licenciaturas da Universidade da Integração Internacional da Lusofonia Afro-Brasileira

Cooperação Sul-Sul, a Universidade da Integração Internacional da Lusofonia Afro-Brasileira atende à diretrizes internacionais de ampliação da oferta de cursos superiores em regiões carentes, das relações de cooperação com 0 continente africano (UNESCO, 2009). A universidade busca construir uma ponte histórica e cultural entre o Brasil e os países de língua portuguesa, especialmente os da África, compartilhando soluções inovadoras para processos históricos similares. (DIÓGENES; AGUIAR, 2013, p. 07).

Em vez de interculturalidade, como podemos ver, sua proposta é construir uma "ponte histórica e cultural" (DIÓGENES; AGUIAR, 2013) e, por meio desta ponte, compartilhar soluções para os processos históricos similares. De fato, além do mesmo colonizador (Portugal), os países de onde provêm as/os estudantes, possuem características similares às brasileiras, ainda que apresentem outras bem distintas e peculiares como podemos ver no Quadro 1.

\section{QUADRO 1 - Levantamento de Características dos Países Africanos}

\begin{tabular}{|c|c|c|}
\hline PAÍS & CARACTERÍSTICAS OFICIAIS & $\begin{array}{c}\text { CARACTERISTICAS } \\
\text { APONTADAS PELAS/OS } \\
\text { ESTUDANTES }\end{array}$ \\
\hline Angola & $\begin{array}{l}\text { É um país com uma extensão territorial } \\
\text { de } 1.246 .700 \mathrm{~km} 2 \text {, localiza-se na costa } \\
\text { ocidental da África, sua capital é Luanda. } \\
\text { Além do Português que é a língua oficial, } \\
\text { Kikongo, Chokwe, Umbundu, Kimbundu, } \\
\text { Nganguela e Kwanyama têm status de } \\
\text { línguas nacionais. O IDH do país é } 0,533 \\
\text { e sua independência de Portugal foi em } \\
11 \text { de novembro de } 1975 \text {. }\end{array}$ & $\begin{array}{l}\text { "Possui mais de } 19 \text { línguas } \\
\text { nativas com predominância } \\
\text { para o Kikongo no Norte, o } \\
\text { Quimbundo no Centro- } \\
\text { oeste e o Ovimbundo no } \\
\text { Centro-sul". (Q42). } \\
\text { "Atualmente está na sua } \\
\text { terceira república, com a } \\
\text { promulgação da } \\
\text { constituição de 2010, é } \\
\text { presidido por João } \\
\text { Gonçalves Lourenco, } \\
\text { membro do Movimento } \\
\text { Popular para a Libertação } \\
\text { de Angola - MPLA, partido } \\
\text { no poder desde a } \\
\text { independência do país" } \\
\text { (Q42). "No aspecto político é } \\
\text { complexo porque existe } \\
\text { muita interferência nos } \\
\text { órgãos institucionais, quem } \\
\text { tem poder muitas vezes } \\
\text { abusa dele e nem sequer é } \\
\text { responsabilizado, acontece } \\
\text { muita intolerância política" } \\
\text { (Q20). }\end{array}$ \\
\hline
\end{tabular}


Opção Decolonial e Práxis Curriculares de Enfrentamento do Racismo: diálogos com sujeitos curriculantes de licenciaturas da Universidade da Integração Internacional da Lusofonia Afro-Brasileira

\begin{tabular}{|c|c|c|}
\hline Cabo Verde & $\begin{array}{l}\text { É um país insular localizado num } \\
\text { arquipélago formado por dez ilhas } \\
\text { vulcânicas na região central do Oceano } \\
\text { Atlântico. A cerca de } 570 \text { quilômetros da } \\
\text { costa da África Ocidental, as ilhas } \\
\text { cobrem uma área total de pouco mais de } \\
4.000 \text { km2. Sua capital é Praia. A língua } \\
\text { oficial é o Português, mas existe uma } \\
\text { comunidade de imigrantes senegaleses, } \\
\text { especialmente na ilha do Sal, que fala } \\
\text { também francês e na cidade da Praia, } \\
\text { uma comunidade de imigrantes } \\
\text { nigerianos que fala inglês. O IDH do país } \\
\text { é 0,648. A } 19 \text { de Dezembro de } 1974 \text {, foi } \\
\text { assinado um acordo entre o "Partido } \\
\text { Africano para a Independência da Guiné } \\
\text { e Cabo Verde" (PAIGC), e Portugal, } \\
\text { instaurando-se um governo de transição } \\
\text { em Cabo Verde, governo esse que } \\
\text { preparou as eleições para uma } \\
\text { Assembleia Nacional Popular. A } 5 \text { de } \\
\text { Julho de 1975, proclamou-se a } \\
\text { independência do país. }\end{array}$ & $\begin{array}{l}\text { É muito bonito meu país. } \\
\text { Por causa do turismo que é } \\
\text { muito forte sempre se } \\
\text { destaca as nossas belezas } \\
\text { naturais. Também podemos } \\
\text { dizer que somos um povo } \\
\text { muito guerreiro. Muito } \\
\text { combativo, muito forte. Mas } \\
\text { tem o problema da } \\
\text { concentração da renda em } \\
\text { poucas mãos. Embora todo } \\
\text { mundo se vire, nossas } \\
\text { riquezas não são bem } \\
\text { divididas, não" (Q56). }\end{array}$ \\
\hline $\begin{array}{l}\text { Guiné- } \\
\text { Bissau }\end{array}$ & $\begin{array}{l}\text { É um país da África Ocidental, cuja } \\
\text { capital é Bissau, possui uma extensão } \\
\text { territorial de } 36.125 \mathrm{Km} 2 \text {. Apenas } 27,1 \% \\
\text { da população fala português (primeira ou } \\
\text { segunda língua), estabelecido como } \\
\text { língua oficial durante o período colonial. } \\
\text { A grande maioria da população (90,4\%) } \\
\text { fala Kriol, uma língua crioula baseada no } \\
\text { português, que é reconhecida, mas não } \\
\text { é oficial, enquanto o restante dos } \\
\text { habitantes fala uma variedade de línguas } \\
\text { africanas nativas. Possui um IDH de } \\
0,424 \text {. Em 1956, Amílcar Cabral liderou a } \\
\text { fundação do Partido Africano para a } \\
\text { Independência da Guiné e Cabo Verde } \\
\text { (PAlGC), que, no início da década de } \\
1960 \text {, iniciou a luta armada contra o } \\
\text { regime colonial. Teve a independência } \\
\text { de Portugal declarada em } 24 \text { de } \\
\text { setembro de } 1973 \text {, a qual só foi } \\
\text { reconhecida em } 10 \text { de setembro de } \\
1974 \text {. }\end{array}$ & $\begin{array}{l}\text { "Temos como língua oficial, } \\
\text { o português, mas falamos a } \\
\text { língua crioula que é o elo da } \\
\text { ligação entre todos os } \\
\text { Guineenses, e as línguas } \\
\text { étnicas" (Q3). } \\
\text { "Em termos políticos, como } \\
\text { sendo um país jovem com } \\
43 \text { anos de independência, } \\
\text { não tem um sistema político } \\
\text { governamental bem estável } \\
\text { com constantes golpes de } \\
\text { estado. Desde } \\
\text { proclamação da } \\
\text { independência até os dias } \\
\text { de hoje não tem um } \\
\text { governo que terminou seu } \\
\text { mandato" (Q35). } \\
\text { "Falando da cultura é um } \\
\text { dos aspectos que me fazem } \\
\text { ter muito orgulho de ser } \\
\text { daquele país, as danças } \\
\text { tradicionais, as músicas, as } \\
\text { vestes... quando chega o } \\
\text { carnaval cada grupo se } \\
\text { preparando para dar o } \\
\text { melhor de si e mostrar o } \\
\text { melhor de cada área, as }\end{array}$ \\
\hline
\end{tabular}


Opção Decolonial e Práxis Curriculares de Enfrentamento do Racismo: diálogos com sujeitos curriculantes de licenciaturas da Universidade da Integração Internacional da Lusofonia Afro-Brasileira

\begin{tabular}{|c|c|c|}
\hline & & $\begin{array}{l}\text { máscaras, o "nturudu", as } \\
\text { meninas de saia de } \\
\text { "budjugu", é tudo uma } \\
\text { coisa bonita para se ver e é } \\
\text { tão encantador!!" (Q34). }\end{array}$ \\
\hline Moçambique & $\begin{array}{l}\text { É um país localizado no sudeste do } \\
\text { Continente Africano, banhado pelo } \\
\text { Oceano Índico. Sua capital é Maputo. O } \\
\text { país tem uma área de } 801.590 \mathrm{Km} 2 \text {. A } \\
\text { única língua oficial de Moçambique é o } \\
\text { Português, que é falado principalmente } \\
\text { como segunda língua por cerca de } \\
\text { metade da população. Entre as línguas } \\
\text { nativas mais comuns estão o Macua, o } \\
\text { Tsonga e o Sena. Seu IDH é 0,418. A } \\
\text { Frente de Libertação de Moçambique } \\
\text { (FRELIMO) iniciou uma campanha de } \\
\text { guerrilha contra o governo português em } \\
\text { setembro de 1964, após dez anos de } \\
\text { guerra Moçambique tornou-se } \\
\text { independente de Portugal em } 25 \text { de } \\
\text { junho de } 1975 \text {. }\end{array}$ & $\begin{array}{l}\text { "Meu país está se } \\
\text { desenvolvendo, } \\
\text { industrialmente falando. } \\
\text { Mas ainda temos muitos } \\
\text { problemas. Principalmente } \\
\text { na educação. É muito difícil } \\
\text { a educação ali. Falta muita } \\
\text { escola, e pra você ter uma } \\
\text { boa oportunidade tem que } \\
\text { estudar fora" (Q18). } \\
\text { "Parece com o Brasil em } \\
\text { muitas coisas, na cultura, } \\
\text { na alegria. Mas os pobres } \\
\text { de Moçambique são muito } \\
\text { pobres. Tem muito } \\
\text { crescimento mas ainda não } \\
\text { chegou pra todo mundo" } \\
\text { (Q68). }\end{array}$ \\
\hline $\begin{array}{l}\text { São Tomé e } \\
\text { Príncipe }\end{array}$ & $\begin{array}{l}\text { É um estado insular localizado no Golfo } \\
\text { da Guiné, composto por duas ilhas } \\
\text { principais (Ilha de São Tomé e Ilha do } \\
\text { Príncipe) e várias ilhotas, num total de } \\
1001 \mathrm{~km}^{2} \text {, cuja capital é São Tomé. O } \\
\text { Português é a língua oficial e de fato a } \\
\text { nacional de São Tomé e Príncipe é } \\
\text { falada por cerca de } 98,4 \% \text { da população } \\
\text { do país. Variantes reestruturadas de } \\
\text { português ou crioulos portugueses } \\
\text { também são falados como o Forro (a } \\
\text { linguagem das redes sociais para } \\
\text { aqueles com idade acima de } 30 \text { é falado } \\
\text { por } 36,2 \% \text { ), O Crioulo Cabo-Verdiano } \\
\text { (8,5\%), o Angolar (6,6\%) e o Principense } \\
(1 \%) \text { Seu IDH é } 0,574 \text {. Conquistou } \\
\text { independência de Portugal em } 12 \text { de } \\
\text { julho de } 1975 \text {. }\end{array}$ & $\begin{array}{l}\text { "Constitui uma 'pequena } \\
\text { babel', pois além do } \\
\text { português residem os } \\
\text { crioulos, forro, lung'ie, } \\
\text { angolar, fa dambô, } \\
\text { caboverdiano e português } \\
\text { dos tongas [...] em termos } \\
\text { culturais existem marcas } \\
\text { que se assemelham à } \\
\text { cultura brasileira. Observo } \\
\text { isso, na arquitetura dos } \\
\text { prédios, nas nossas danças } \\
\text { e a gastronomia, constatei } \\
\text { essa semelhança na } \\
\text { comida baiana: o picante, } \\
\text { uso do azeite de dendê e } \\
\text { quiabo". (Q38) }\end{array}$ \\
\hline
\end{tabular}

Fonte: Ferreira, 2018, p. 54.

Percebemos, tanto nos dados oficiais, como nos dados levantados a partir dos questionários que as fragilidades econômicas e sociais, instabilidade política e riquezas naturais e culturais estão nas duas cabeças da ponte histórica e cultural construída pela UNILAB. Também percebemos que mesmo as/os estudantes ficam presas/os a questões similares às oficiais para descrever seus países, mas um dos principais elementos citados que cruzam 
Opção Decolonial e Práxis Curriculares de Enfrentamento do Racismo: diálogos com sujeitos curriculantes de licenciaturas da Universidade da Integração Internacional da Lusofonia Afro-Brasileira

tal ponte é a própria lusofonia. Esta que é a estratégia utilizada para promover a integração com a África é uma das principais feridas que carregamos do processo colonizador: "É muito comum, ver nos corredores da Universidade as/os estudantes conversando entre si em suas línguas étnicas e, apenas quando nos dirigimos a elas/es, é que falam em português" (Diário de Campo 05/04/2018), tal como nos mostra Fanon (2008, p. 33):

O negro tem duas dimensões. Uma com seu semelhante e outra com o branco. Um negro comporta-se diferentemente com o branco e com outro negro. Não há dúvida de que esta cissiparidade é uma consequência direta da aventura colonial... [...] Falar é estar em condições de empregar uma certa sintaxe, possuir a morfologia de tal ou qual língua, mas é sobretudo assumir uma cultura, suportar o peso de uma civilização.

As línguas étnicas representam resistência histórica e cultural, embora, na maioria delas, não seja valorizada uma atitude de desobediência epistêmica que é justamente utilizar a língua colonial para desestabilizar o conhecimento único, pois embora a Universidade se constitua a partir da integração da lusofonia, é a questão afro-brasileira que ganha destaque em seu projeto.

Outro propósito da UNILAB, dentro da perspectiva da interiorização do ensino superior, é contribuir para diminuir as desigualdades socioeconômicas identificadas em diversos índices nacionais que apontam a região nordeste brasileira como uma das mais carentes do país. Dessa forma, as localidades onde os campi da Universidade foram instalados se localizam nesta região e não foram escolhidos aleatoriamente.

Redenção (CE) foi a primeira cidade brasileira a, oficialmente, decretar a abolição da escravatura, em 1883. São Francisco do Conde (BA) é a terceira cidade do Recôncavo Baiano (com 31.699 habitantes, segundo o Instituto Brasileiro de Geografia e Estatística - IBGE) e é considerado o município de maior população negra (maior que 90\%) declarada no censo. Estes dados trazem uma especificidade e uma identidade à universidade, porém, mais uma vez nos confrontamos com as tensões entre os dados oficiais e a realidade cotidiana. Pois, por mais significativos que sejam os dados oficiais para a escolha do local de implantação da universidade eles não representam, necessariamente, que estes locais estejam isentos do racismo, ou mesmo, estejam abertos a enfrentá-lo.

Oficialmente, Redenção, no Ceará, foi eleita devido ao reconhecimento do ato histórico de ser a primeira cidade no Brasil a abolir a escravidão negra, fato que decorreu da criação em 1882 da "Sociedade Redentora Acarapense", sociedade que reunia pessoas com ideais abolicionistas. Assim, em 1 de janeiro de 1883, chegavam à então Vila Acarape, dentre outros abolicionistas, Liberato Barroso, Antônio Tibúrcio, Justiniano de Serpa, José do Patrocínio e João Cordeiro (note-se que são citados nome e sobrenome), com a finalidade 
Opção Decolonial e Práxis Curriculares de Enfrentamento do Racismo: diálogos com sujeitos curriculantes de licenciaturas da Universidade da Integração Internacional da Lusofonia Afro-Brasileira

de assistirem a alforria de 116 pessoas escravizadas do lugarejo (das quais não temos o registro de seus nomes). A partir daquele ato, a vila recebe 0 nome de Redenção.

Apesar de tal fato histórico, a cidade ainda cultiva o imaginário da escravidão muito mais do que o da "redenção", seja nos monumentos erigidos, seja nas atitudes racistas narradas pelas/os estudantes negros/as, tanto brasileiros/as como africanos/as, como nos mostra o estudante guineense:

residindo no Brasil concretamente na cidade de Redenção há 5 anos, uma cidade marcada pelo racismo, [...] pois atitudes racistas fazem parte do meu cotidiano, nos Supermercados, farmácias, lojas de venda, na universidade. Racismo na cidade de Redenção está num processo de naturalização, pois a forma como, às vezes é expressa, externaliza a atitude inconsciente do indivíduo racista. (Q32, p. 183).

O que o estudante chama de processo de naturalização está atrelado ao que chamamos de Colonialidade, pois o padrão ou a matriz de poder constituída está pautada nessa ideia de que a divisão racial da sociedade é algo natural, como veremos mais adiante.

A pressão da instalação da UNILAB coloca em xeque as feridas coloniais da cidade com a chegada de estudantes africanos, em sua maioria negras/os, pois como observa uma estudante moçambicana do campus baiano da UNILAB, ao participar de um evento $^{5}$ na cidade de Redenção nos diz admirada: "Como os brasileiros no Ceará são brancos!" (Diário de Campo, 06/04/18). E a admiração da estudante encontra respaldo nos dados do IBGE (2010) que mostram que a população cearense é constituída por 33,05\% de pessoas que se autodeclaram brancas; 63,39\%, pardas; 1,53\% indígenas e $3,03 \%$ pretas.

Nesse sentido, fica evidenciado que o fato de ser o pioneiro a abolir a escravatura não representou uma mudança na forma da integração da população negra à sociedade, pois quando perguntamos em uma visita ao Museu da cidade sobre as 116 pessoas que foram libertas da escravidão em 1883 na cidade, a pergunta foi recebida com espanto e respostas vagas mostram que não houve uma preocupação com esta população (Diário de Campo, 10/05/2018). Por isso, a volta de pessoas negras ao cotidiano da cidade não condiz com a expectativa de uma sociedade antirracista e aponta um grande desafio para a UNILAB.

O campo de nossa pesquisa foram quatro licenciaturas dos campi do Ceará. Os cursos de História, Pedagogia e Sociologia estão sediados na

\footnotetext{
${ }^{5}$ II Seminário de Estudos Africanos: Estado, Nação e Cultura para além das Fronteiras. Ocorreu entre os dias 05 a 07 de abril de 2018 no Campus Liberdade em RedençãoCE/UNILAB.
} 
Opção Decolonial e Práxis Curriculares de Enfrentamento do Racismo: diálogos com sujeitos curriculantes de licenciaturas da Universidade da Integração Internacional da Lusofonia Afro-Brasileira

Unidade Acadêmica Palmares, situada à Rodovia CE 060 - Km 51 - Acarape CE - Brasil e o curso de Letras está no Campus Liberdade, localizada à Av. da Abolição, no 3 - Centro - Redenção - CE ${ }^{6}$. Embora estejam em municípios distintos, há uma comunicação entre os campi, por meio de um ônibus circular da universidade que transporta as pessoas durante os turnos de funcionamento das duas unidades. No Quadro 2 podemos ter uma visão mais detalhada da identificação dos cursos.

\begin{tabular}{|c|c|c|c|c|c|}
\hline \multirow{2}{*}{\multicolumn{2}{|c|}{ ESTRUTURANTES }} & \multicolumn{4}{|c|}{ CURSOS DE FORMAÇÃO DE PROFESSORAS/ES } \\
\hline & & HISTÓRIA & LETRAS & PEDAGOGIA & SOCIOLOGIA \\
\hline \multicolumn{2}{|c|}{ Denominação do curso } & $\begin{array}{c}\text { Curso de } \\
\text { Licenciatura } \\
\text { em História }\end{array}$ & $\begin{array}{l}\text { Curso de } \\
\text { Graduação } \\
\text { em Letras - } \\
\text { Língua } \\
\text { Portuguesa }\end{array}$ & $\begin{array}{l}\text { Licenciatura } \\
\text { em Pedagogia }\end{array}$ & $\begin{array}{c}\text { Curso de } \\
\text { Licenciatura } \\
\text { em Sociologia }\end{array}$ \\
\hline \multirow{2}{*}{$\begin{array}{l}\text { Duração do } \\
\text { curso }\end{array}$} & Mínima & 4 anos & 4,5 anos & 3 anos & 3 anos \\
\hline & Máxima & 5,5 anos & $\begin{array}{l}\text { Em processo } \\
\text { de regulação } \\
\text { interna }\end{array}$ & Não informado & 4,5 anos \\
\hline \multicolumn{2}{|c|}{ Modalidade } & \multicolumn{4}{|c|}{ Presencial } \\
\hline \multirow{2}{*}{\multicolumn{2}{|c|}{$\begin{array}{l}\text { Regime Letivo } \\
\text { Turnos de oferta }\end{array}$}} & \multicolumn{4}{|c|}{ Seriado Semestral } \\
\hline & & Noturno & $\begin{array}{l}\text { Integral com } \\
\text { concentração } \\
\text { no noturno }\end{array}$ & Noturno & Noturno \\
\hline & 80 & 80 & 80 & 80 \\
\hline \multicolumn{2}{|l|}{ Carga-horária } & 3.345 horas & 3.200 horas & 4.400 horas & 3.570 horas \\
\hline \multirow{2}{*}{\multicolumn{2}{|c|}{$\begin{array}{l}\text { Unidade acadêmica } \\
\text { responsável pela oferta } \\
\text { Título acadêmico }\end{array}$}} & \multicolumn{4}{|c|}{ Instituto de Humanidades e Letras $-\mathrm{IHL}^{7}$} \\
\hline & 0 & $\begin{array}{l}\text { Licenciado } \\
\text { em História }\end{array}$ & Licenciado & $\begin{array}{l}\text { Licenciado/a } \\
\text { em Pedagogia }\end{array}$ & $\begin{array}{l}\text { Licenciado em } \\
\text { Sociologia }\end{array}$ \\
\hline
\end{tabular}

Fonte: Ferreira, 2018, p. 185.

Cada curso vai responder aos objetivos do desenvolvimento local e internacional a partir de sua implantação, como por exemplo, "A licenciatura em Pedagogia UNILAB emerge com a missão de formar profissionais pautados pelo compromisso de respeitar, valorizar e disseminar os valores e princípios de base africanos e afro-brasileiros" (PPC-PEDAGOGIA, p. 16), assim como para o curso de Sociologia inserir o ensino de Sociologia combina

\footnotetext{
${ }^{6}$ No final da coleta/produção de dados, o curso de Letras se desvinculou do Instituto de Humanidades e Letras, em conformidade às portaria № 926/2018 e № 928/2018, publicadas no Diário Oficial da União em 24 de agosto do corrente ano, foi extinto o Instituto de Humanidades e Letras - IHL, tendo sido criados o Instituto de Humanidades - IH e o Instituto de Linguagens e Literatura - ILL.

${ }^{7}$ Esta foi a organização considerada até o encerramento de nossa coleta/produção de dados. No final de agosto, como mencionamos em nota anterior o IHL foi dissolvido e criado o $\mathrm{IH}$ onde continuam as licenciaturas de História, Pedagogia e Sociologia e o bacharelado em Antropologia. E foi criado também o ILL que ficou com a licenciatura em Letras.
} 
Opção Decolonial e Práxis Curriculares de Enfrentamento do Racismo: diálogos com sujeitos curriculantes de licenciaturas da Universidade da Integração Internacional da

com a discussão ampla sobre cidadania, pós-colonialismo, desigualdade, papel do Estado, dentre outros, em um momento de consolidação e desenvolvimento das instituições locais no plano de sua comunicação com o resto do mundo. (PPCSOCIOLOGIA, p. 08).

A justificativa para o curso de Letras, entre outras questões, aponta para os resultados de Avaliações como o PISA e o IDEB para assinalar a carência da formação na área, alegando que os tais

dados nos indicam o quanto é necessária a melhoria do ensino de língua portuguesa na educação básica em nosso país e especialmente na região Nordeste, como também nos remetem à questão da formação de professores de língua portuguesa e à influência de tal formação no processo de ensinoaprendizagem de língua materna. (PPC-LETRAS, p. 09).

Em sintonia com esta preocupação, os cursos preveem, como principal campo de atuação das/os discentes egressas/os desses Cursos, a docência no Sistema de Educação Básica do Estado do Ceará, dos Municípios do Maciço do Baturité e Região Metropolitana de Fortaleza. E para as/os discentes internacionais há a possibilidade de inserção nos sistemas de Educação em seus países de origem.

Os Projetos Pedagógicos dos Cursos (PPC) foram construídos por comissões constituídas para esta finalidade, em atendimento ao disposto no Plano de Desenvolvimento Institucional (PDI) da instituição, mas além de professoras/es da própria UNILAB e convidadas/os para consultoria da Universidade Federal do Ceará, o curso de Pedagogia se destaca ao convidar para compor a comissão de implantação do curso "o Mestre de Capoeira Magnata e o Mestre Armandinho, considerando a perspectiva afrocentrada e os valores afro-civilizatórios" (PPC-PEDAGOGIA., p. 9), demonstrando uma sensibilidade e uma disposição em valorizar os saberes múltiplos na constituição do curso que formará professoras/es orientadas/os por esta perspectiva e por estes valores.

Os cursos foram organizados em eixos/núcleos e, com base nestes, distribuem sua carga-horária em Teórica, Prática como Componente Curricular e Extensão, de acordo com as diretrizes curriculares nacionais para os referidos cursos. Todos os cursos advêm do primeiro ciclo que compõe o Bacharelado em Humanidades (BHU), assim, as/os estudantes passam pela formação com base nesse núcleo obrigatório de conhecimentos em Humanidades e pelo núcleo obrigatório comum da UNILAB.

Quando ingressam no segundo ciclo de formação vão cursar os núcleos da formação básica em cada campo, da formação específica, da pedagógica, das optativas e eletivas. Além disso, constroem TCC (Trabalho de Conclusão 
Opção Decolonial e Práxis Curriculares de Enfrentamento do Racismo: diálogos com sujeitos curriculantes de licenciaturas da Universidade da Integração Internacional da Lusofonia Afro-Brasileira

de Curso) e participam de atividades complementares e de extensão. Todas estas atividades estão previstas no PDI e nos referidos PPC. A seguir vamos conhecer os sujeitos da pesquisa.

\section{Os Sujeitos - Sujeitos Curriculantes Autoras/es Autorizadas/os}

Nesta seção apresentamos os sujeitos da pesquisa, que assumiam o papel de sujeitos curriculantes com opções teóricas e práticas reconhecidas e apontadas como aquelas que satisfatoriamente abordam o racismo.

Falar sobre estes sujeitos sempre nos remete ao provérbio africano que ensina que: "os caçadores sempre serão os vencedores nas histórias das caçadas, enquanto os leões não contarem estas mesmas histórias". As histórias referem-se ao direito epistêmico, enquanto que os caçadores e leões referem-se aos sujeitos, aos atores sociais que exercem o protagonismo ou a mera figuração.

Contar "as histórias das caçadas" é um ato político e epistêmico reivindicado por pelo menos duas perspectivas, a da Modernidade e a da Colonialidade. Fanon (1968, p. 28) nos mostra que "o mundo colonizado é um mundo cindido em dois" e nos dizia do quanto era supérfluo falar dos exemplos dessa divisão, ainda assim, lembrava-nos do Apartheid na África do Sul; da existência das cidades indígenas e das cidades europeias; das escolas para indígenas e das escolas para europeus. A cisão necessária para separar dentro do projeto da Modernidade os "outros", aqueles que teriam suas histórias apagadas, aqueles que não são capazes de ser porque não são capazes de pensar.

Todavia, dentro da perspectiva da Colonialidade, projetos outros estavam/estão sendo tecidos, enquanto a da Modernidade atuava/atua, e apesar de toda subalternização, sangue e suor derramados; das cinzas das resistências germinam projetos de decolonialidade e lutas por justiça social e epistêmica.

Segundo Arturo Escobar (2003, p. 67), "este proyecto se refiere a la rearticulación de los designios globales por y desde historias locales; con la articulación entre conocimiento subalterno y hegemónico desde la perspectiva de lo subalterno". A primeira questão que apresentamos aqui é a que na cisão do mundo colonizado, as histórias não universais, ou melhor, não universalizadas, não foram totalmente apagadas. Estas histórias ditas locais, na diversalidade do pensamento, evidenciam formas de vida, de resistência e de conhecimento de sujeitos tecidas na diferença colonial.

Os damnés de la terre, os oprimidos, os subalternizados, os "outros" apesar de toda a negação, invisibilidade, marginalização a que são submetidos, pressionam com suas lutas por visibilidade, reconhecimento, 
Opção Decolonial e Práxis Curriculares de Enfrentamento do Racismo: diálogos com sujeitos curriculantes de licenciaturas da Universidade da Integração Internacional da Lusofonia Afro-Brasileira

valorização e, acima de tudo, por seus direitos. Assim, se questionarmos por que a teorias curriculares passaram a se preocupar com as questões étnicas, raciais, de gênero, queer, de classe? Porque se radicalizou a consciência dos direitos entre aquelas/es que foram marcadas/os pela ferida colonial como inferiores, subalternos, selvagens, pobres, atrasados e, na escola, como defasados, repetentes, indisciplinados etc.

Estes sujeitos tiveram a autoria de seus conhecimentos e de suas identidades sucumbida por meio de negações históricas, políticas, sociais, econômicas, patriarcais, cis-heteronormativas, entre outras, contudo, através de atitudes decolonizadoras e não subservientes, vão reivindicar direitos por meio de sua própria autorização.

Conforme Roberto Sidnei Macedo (2013, p. 93), tal autorização "está ancorada na nossa condição de decidir sobre meios que dependem efetivamente de nós, como princípios que governam nossa existência". Ou seja, reivindicar a própria autorização é a "capacidade adquirida e conquistada de alguém se fazer a si mesmo autor" (2013, p. 93). Autorizar-se está relacionado ao processo de conscientização que Freire (2005) nos falava, o qual se refere ao reconhecimento de sua situação (de oprimido, subalternizado, colonizado etc.) e da ação decorrente de tal reconhecimento que vai de encontro ao ajustamento ao que está estabelecido, em direção da libertação, decolonização, retomada de sua condição de autora/or.

Assim, a seleção de sujeitos para a nossa pesquisa se fez por meio de uma busca de conceitos experienciais ou, como nos mostra Michael Agar (1996, p. 90), "experience near concepts", isto é, como as/os sujeitos curriculantes concebem, vivem e atribuem sentido ao racismo. Por isso, a entrevista não diretiva permite uma maior flexibilidade para que possamos construir juntas/os as pautas da conversa/entrevista, colocando-nos em uma postura de abertura às prioridades, temas e problemáticas que possam revelar - que é racismo e práticas de seu enfrentamento dentro do universo sociocultural a que pertencem os sujeitos da pesquisa por meio da livre associação que os sujeitos fazem dos temas incialmente propostos.

Guber (2001) parte da premissa que mesmo em uma entrevista não diretiva, nós pesquisadoras/es debruçamo-nos sobre o conhecimento a partir de nossa bagagem conceitual e de nossos sensos comuns, por isso é imprescindível que, para captar os conceitos que vamos buscar no campo empírico, estejamos sempre em uma postura de escuta para não privilegiarmos de antemão algum ponto do discurso que referende nossas impressões iniciais, a que já levamos conosco em nossa bagagem. A autora defende que

Este procedimiento se diferencia del empleado en las encuestas y cuestionarios porque la libre asociación permite introducir temas y conceptos desde la perspectiva del informante más que desde la del investigador. Promover la libre 
Opção Decolonial e Práxis Curriculares de Enfrentamento do Racismo: diálogos com sujeitos curriculantes de licenciaturas da Universidade da Integração Internacional da Lusofonia Afro-Brasileira asociación deriva en cierta asimetría "parlante" en la entrevista etnográfica, con verbalizaciones más prolongadas del informante, y mínimas o variables del investigador. (2001, p. 33).

Para auxiliar no processo de análise, gravamos o áudio das entrevistas, para posterior transcrição e sistematização que foram analisados por meio da Técnica da Análise de Conteúdo, via Análise Temática (BARDIN, 2011; VALA, 1990). Os dados registrados no Diário de Campo serviram como orientadores na elaboração das questões/pautas das entrevistas.

O contato com os sujeitos da pesquisa se deu primeiramente com as/os estudantes. Em nossa primeira semana na instituição, seis estudantes (cinco de Guiné-Bissau e um de São Tomé e Príncipe), dos cursos de Letras (um), Pedagogia (dois) e Sociologia (três) foram voluntárias/os na (re)construção de um Questionário de Identificação. O objetivo do questionário foi identificar os componentes curriculares que, na opinião das/os estudantes, abordavam 0 tema do racismo satisfatoriamente, para elegermos os sujeitos curriculantes discentes e docentes que seriam entrevistadas/os.

Em seguida, buscamos entrevistar dentre aquelas/es que responderam os questionários, estudantes de cada curso, respeitando a paridade de gênero e um equilíbrio entre os países, mas a dinâmica local nos levou a outras configurações. Um estudante de História e um de Sociologia foram indicados por dois dos docentes entrevistados, devido à sua participação ativa em projetos de extensão e de pesquisa envolvendo a temática da educação das relações étnico-raciais. Duas estudantes de Letras haviam sido selecionadas pelos questionários, também por sua atuação em atividades de extensão e pesquisa. As/os outras/os estudantes se ofereceram para participar da entrevista quando souberam da nossa pesquisa. Com outras/os estudantes que havíamos selecionado pelos questionários por sua aproximação ao tema da educação das relações étnico-raciais, não conseguimos agendar as entrevistas devido a outras atividades que estavam desenvolvendo no momento.

Vale destacar o quantitativo de estudantes nas graduações em abril de 2018 de acordo com a Diretoria de Registro e Controle Acadêmico (DRCA): 3.976 assim distribuídos por nacionalidade:

- Angola: 180

- Brasil: 2.942

- Cabo Verde: 83

- Guiné-Bissau: 628

- Moçambique: 37

- São Tomé e Príncipe: 78

- Timor Leste: 28 
Opção Decolonial e Práxis Curriculares de Enfrentamento do Racismo: diálogos com sujeitos curriculantes de licenciaturas da Universidade da Integração Internacional da Lusofonia Afro-Brasileira

Como podemos ver (destacado em negrito), a maioria dos estudantes é brasileira e do público estrangeiro a maioria vem de Guiné Bissau, seguido por Angola. Tais dados justificam por que as/os estudantes entrevistadas/os são dessas nacionalidades (Guiné Bissau: 05; Brasil: 04; Angola: 03 e São Tomé e

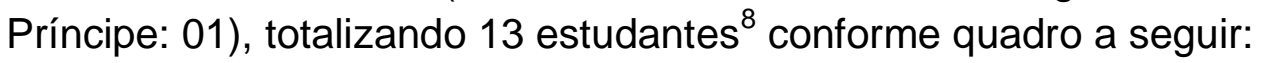

\section{QUADRO 3 - Caracterização Discente}

\begin{tabular}{|c|c|c|c|c|c|}
\hline Curso & Identificação & Nacionalidade & Cor/Raça & Etnia & $\begin{array}{l}\text { Identidade } \\
\text { de Gênero }\end{array}$ \\
\hline \multirow{4}{*}{ HISTÓRIA } & EH1 & Angola & Preto & Ambundo & M \\
\hline & $\mathrm{EH} 2$ & Brasil & Parda & & $\mathrm{F}$ \\
\hline & EH3 & Guiné-Bissau & Preto & Papel & $M$ \\
\hline & EL1 & Angola & Preto & Bakongo & $\mathrm{M}$ \\
\hline \multirow{4}{*}{ LETRAS } & EL2 & Brasil & Parda & - & $\mathrm{F}$ \\
\hline & EL3 & Guiné-Bissau & Preta & Papel & $\mathrm{F}$ \\
\hline & EL4 & Guiné-Bissau & Preta & Papel & $\mathrm{F}$ \\
\hline & EL5 & $\begin{array}{l}\text { São Tomé e } \\
\text { Príncipe }\end{array}$ & Branca & - & $\mathrm{F}$ \\
\hline \multirow{2}{*}{ PEDAGOGIA } & EP1 & Brasil & Branca & - & $\mathrm{F}$ \\
\hline & EP2 & Guıne-Bissau & Preta & Macanha & $\mathrm{F}$ \\
\hline \multirow{3}{*}{ SOCIOLOGIA } & & Alyola & & - & \\
\hline & & Gunǵ Ding & arcuo & M. & IVI \\
\hline & & Gumle-bIssau & & IVISta & $r$ \\
\hline
\end{tabular}

Fonte: Questionários de Identificação Discente

Em relação ao corpo docente, entramos em contato com as coordenações de cada curso para mediar o contato com as/os professoras/es das disciplinas que foram apontadas pelas/os estudantes nos questionários. Assim, entramos em contato com as/os professoras/es via e-mail, marcando as datas para a realização das entrevistas. Não foi possível assistir aulas das disciplinas indicadas, pois elas não estavam sendo oferecidas neste período. As/os estudantes indicaram as disciplinas que já haviam cursado, por essa razão não pudemos realizar observações das aulas.

As entrevistas foram realizadas ao longo de uma semana, durante nossa última estadia em agosto de 2018. Da mesma forma que as/os estudantes, as/os professoras/es assinaram o Termo de Consentimento Livre e Esclarecido, dois professores autorizaram prontamente sua identificação, uma professora no primeiro momento não se sentiu à vontade, mas depois autorizou. Porém, como dois professores preferiram não se identificar, também vamos usar códigos para todas/os.

\footnotetext{
${ }^{8}$ Antes das entrevistas, cada estudante assinava um Termo de Consentimento Livre e Esclarecido no qual autorizava ou não sua identificação. Apenas um estudante autorizou sua identificação. Dessa forma, para manter o anonimato das/os demais, vamos usar códigos em vez de seus nomes.
} 
Opção Decolonial e Práxis Curriculares de Enfrentamento do Racismo: diálogos com sujeitos curriculantes de licenciaturas da Universidade da Integração Internacional da

\section{QUADRO 4 - Caracterização Docente}

Lusofonia Afro-Brasileira

$\begin{array}{ccccc}\text { Curso } & \text { Identificação } & \begin{array}{c}\text { Nacionalidade } \\ \text { Crasil }\end{array} & \begin{array}{c}\text { Cor/Raça } \\ \text { Preto }\end{array} & \begin{array}{c}\text { Identidade } \\ \text { de Gênero }\end{array} \\ \text { HISTÓRIA } & \text { PH1 } & \text { Argentina } & \text { Branca } & \mathrm{F} \\ & \text { PH2 } & \text { Argat } & \text { Preto } & \text { M } \\ \text { PEDAGOGIA } & \text { PP1 } & \text { Brasil } & \text { Pardo } & \text { M } \\ \text { SOCIOLOGIA } & \text { PS1 } & \text { Brasil } & \text { Branca } & \text { F }\end{array}$

Fonte: Questionários de Identificação Docente

A coordenação de Letras não retornou o nosso contato e, assim, não conseguimos agendar entrevista com nenhuma/um docente do curso. Vale destacar que durante a semana que estávamos realizando as entrevistas, 0 IHL estava em processo de dissolução e em período eleitoral para coordenação, o que alterava a rotina do quadro docente.

A seguir apresentamos os elementos de práxis decolonizadora e de enfrentamento do racismo encontradas nas práticas curriculares a partir das concepções de racismo dos sujeitos curriculantes.

\section{As concepções de racismo dos sujeitos curriculantes}

Nesta seção debruçamo-nos sobre as concepções de racismo dos sujeitos da pesquisa para que possamos nos aproximar das praxis curriculares de enfrentamento do racismo, pois entendemos que estas se materializam a partir da ação-reflexão-ação sobre o fenômeno do racismo como um componente curricular e prática pedagógica.

Nesta seção, focamos exatamente no que dizem os sujeitos curriculantes o que para nós, foi o eixo mais difícil de analisar, pois as concepções de racismo de cada sujeito estão marcadas pela ferida colonial de maneiras distintas e se relacionam com a conformação da própria identidade de cada uma/um. A compreensão que cada sujeito traz sobre o racismo orienta sua ação sobre o modo como abordá-lo, como pudemos compreender conversando ou entrevistando professoras/es e estudantes. Ao longo dos quatro meses de idas e vindas ao campo de pesquisa nos deparamos com compreensões e formas de reações que iam desde 0 uso de determinadas palavras até o modo como se identificar em relação ao quesito raça/cor que situam estes sujeitos no lugar epistêmico de sujeitos curriculantes que são autoras/es e autoridades no tema do racismo.

Assim, para organizar a análise em resposta ao objetivo de "analisar as concepções de racismo dos diversos sujeitos curriculantes dos cursos de 
Opção Decolonial e Práxis Curriculares de Enfrentamento do Racismo: diálogos com sujeitos curriculantes de licenciaturas da Universidade da Integração Internacional da Lusofonia Afro-Brasileira
licenciatura", identificamos quatro eixos:
a) definição;
b) tipos;
c) características e; d) sujeitos.

Definições de Racismo: atitudes racistas não são meras brincadeiras

Por ser forjado pela colonialidade que é o lado avesso da modernidade, aquele que não se mostra, o racismo também assume essa característica que torna difícil a formulação de uma explicação para este fenômeno que parece ser autoexplicativo. Tal subterfúgio é uma das ferramentas utilizadas para camuflar sua ação, por exemplo, quando se diz que uma atitude racista é apenas uma brincadeira.

Todavia, não encontramos esta dificuldade entre os sujeitos desta pesquisa. Houve uma unanimidade na definição de racismo como uma hierarquização racial baseada em traços fenotípicos, com algumas considerações que ampliavam tal hierarquização para outras dimensões, igualmente subalternizadas pela colonialidade, como as questões de gênero, território, sexualidade.

Esta compreensão dos sujeitos curriculantes fundamenta-se na força que foi atribuída ao elemento fenotípico na exploração do trabalho a partir da ideia de "raça". Conforme nos explica Quijano (1999), a ideia de "raça" nasceu antes do critério "cor", e este não estava relacionado à racialização, ao menos num primeiro momento. Tanto que a primeira "raça" são os índios, porém o autor nos mostra que:

Sin embargo, las primeras gentes dominadas a las que los futuros europeos aplican la idea de "color" no fueron los "indios. Fueron los esclavos secuestrados y negociados desde las costas de lo que ahora se conoce como África y a quienes se llamará "negros". Pero aunque sin duda parezca ahora extraño, no es a ellos que originalmente se aplica la idea de "raza", a pesar de que los futuros europeos los conocen desde mucho antes de llegar a las costas de la futura América. (QUIJANO, 1999, p. 04).

Como podemos ver, o autor destaca que não foi simultânea a articulação da ideia de "raça" com os traços fenotípicos, como a cor. Porém, quando estes elementos passam a ser articulados, são os negros os que primeiro sofrem sua ação. E assim, se tem elementos suficientes para constituir uma doutrina na qual raça-cor passam a ser praticamente homônimos.

Todas as pessoas entrevistadas ressaltaram a hierarquização racial como elemento central do racismo, não houve uma definição dissonante, assim, entendemos que a definição de racismo dos sujeitos curriculantes são de dois tipos: a) hierarquização fenotípica restrita, a qual baseia a definição apenas nos traços do fenótipo do sujeito (cor da pele, cabelo, entre outros) 
Opção Decolonial e Práxis Curriculares de Enfrentamento do Racismo: diálogos com sujeitos curriculantes de licenciaturas da Universidade da Integração Internacional da Lusofonia Afro-Brasileira

para o estabelecimento de hierarquizações que subalternizam o fenótipo negro e; b) hierarquização fenotípica com ampliações, que além dos traços biológicos do fenótipo interseccionam elementos sociais, econômicos, territoriais, culturais na promoção das hierarquizações, tal como podemos ver no Quadro 5.

\section{QUADRO 5 - Definições de Racismo}

\section{Hierarquização Fenotípica Restrita}

Racismo é a discriminação social baseada no conceito de que existem diferentes raças humanas e que uma é superior às outras. Ou seja, é desrespeitar o outro pela sua cor de pele, cabelos entre outros (ES3).

Pode ser entendida também como uma forma pejorativa de tratar o outro, de se entender melhor que o outro, achando que está em melhor qualidade que o outro já que todos somos seres humanos e temos os mesmos direitos que os outros, é essa forma pejorativa de tratar os outros (EL3).

Olha, a gente pode fazer uma definição conceitual de que racismo é a prática da discriminação de um sujeito ou de uma sujeita a partir de um elemento racial, ou fenótipos, né? Essa seria uma definição, não do que seria o racismo, mas a prática de algo, quando você executa uma ação ou pensamento, ou expressa pensamento, verbaliza algo contra determinadas pessoas a partir de elemento racial, então esses seriam exemplos do que seria racismo. Uma prática de discriminação a partir da raça, de características raciais da pessoa, do sujeito (PP1).

\section{Hierarquização Fenotípica e Ampliações}

Racismo é o julgamento de uma pessoa ou grupo que se considera superior à outra ou outro, ou também desvalorizar alguém por ser de uma classe baixa ou por ter um tom de pele mais escuro. Atitude racista é aquela que pensa que o negro não tem habilidade e somente o branco é capaz de fazer alguma coisa ou por entender que quem vive na zona rural é inferior comparado com aquele que vive na zona urbana (EH1).

Racismo é uma condição social, no início ela surge com um viés biológico de inferior e superior, depois ela não sustenta vai para um lado social, cultural inferior/superior. É uma hierarquia racial $(\mathrm{PH} 1)$.

Um sistema que sustenta um regime de supremacia branca, esse sistema está associado ao sexismo e ao classismo ( $\mathrm{PH} 2)$.

\section{Fonte: Transcrição de Entrevistas.}

As falas acima, bem como outras que não entraram nessa seleção, afirmam a alteridade do sujeito racializado diante do sistema hierarquizador criado no âmbito da Modernidade, o qual desumaniza 0 damnés/oprimido/colonizado. Porém só o faz até o momento em que ele se desloca do lugar social para o lugar epistêmico, e assim, como nos mostra Fanon (1968, p. 32): "O colonizado sabe de tudo isto e dá uma gargalhada 
Opção Decolonial e Práxis Curriculares de Enfrentamento do Racismo: diálogos com sujeitos curriculantes de licenciaturas da Universidade da Integração Internacional da Lusofonia Afro-Brasileira cada vez que aparece como animal nas palavras do outro. Pois sabe que não é um animal. E justamente, no instante mesmo em que descobre sua humanidade, começa a polir as armas para fazê-la triunfar".

De acordo com o autor, apesar dos violentos processos de desumanização o sujeito quando assume seu lugar epistêmico se levanta para a luta para fazer sua humanidade triunfar. E essa atitude decolonial percebemos nos sujeitos curriculantes ao demonstrarem exatamente 0 elemento que subalterniza os seres humanos criando hierarquizações e justificando subalternizações.

Numa compreensão mais restrita os elementos biológicos, ou as características fenotípicas são os primeiros elementos a serem confrontados. Mas, podemos perceber nas definições fenotípicas com ampliações uma posição direcionada para o debate sobre interseccionalidade.

Tais definições rejeitam a ocultação da culpa da Modernidade (DUSSEL, 1994), assim como já expressam um enfrentamento do racismo e da sua dissimulação como abordaremos logo mais na próxima subseção.

\section{Tipos das concepções de racismo ou como são forjadas as feridas coloniais para os sujeitos curriculantes}

Como mencionamos, as pessoas entrevistadas não titubearam ao dar suas definições de racismo, mas durante as entrevistas pudemos perceber que tais definições de racismo se originam a partir dos estudos, de suas vivências ou da empatia. E assim, entendemos que as concepções de racismo dos sujeitos entrevistados podem ser de três tipos: a) teórica; b) prática e; c) empática.

Os tipos de concepção sobre o racismo estão relacionados à ideia da hierarquização fenotípica dos próprios sujeitos, ainda que não seja um ato deliberado ou mesmo consciente de tal, mas observamos que cada um desses tipos foi identificado em determinado grupo fenotípico dentre as/os entrevistadas/os.

As concepções teóricas geralmente se combinam com as outras duas e servem de embasamento para compreensão do fenômeno. Este tipo de concepção teórica foi anunciado tanto pelas pessoas que se autodeclararam negras $^{9}$, como pelas brancas.

As concepções práticas abordam a compreensão do que vem a ser racismo diante de situações vivenciadas diretamente pelo sujeito, ainda que sejam tomadas de maneira confusa. Apenas as pessoas que se autodeclaram pretas anunciaram este tipo de concepção.

\footnotetext{
${ }^{9}$ Por pessoas negras estamos entendendo o conjunto de pessoas que se autodeclaram pretas e pardas, conforme entendimento do IBGE.
} 
Opção Decolonial e Práxis Curriculares de Enfrentamento do Racismo: diálogos com sujeitos curriculantes de licenciaturas da Universidade da Integração Internacional da Lusofonia Afro-Brasileira

E o terceiro tipo de concepções são oriundas de uma atitude de empatia desenvolvida a partir da compreensão das consequências da hierarquização fenotípica, seja ela restrita ou ampliada. Esta foi anunciada por pessoas que se autodeclaram brancas.

\section{Tipos de Concepção de Racismo}

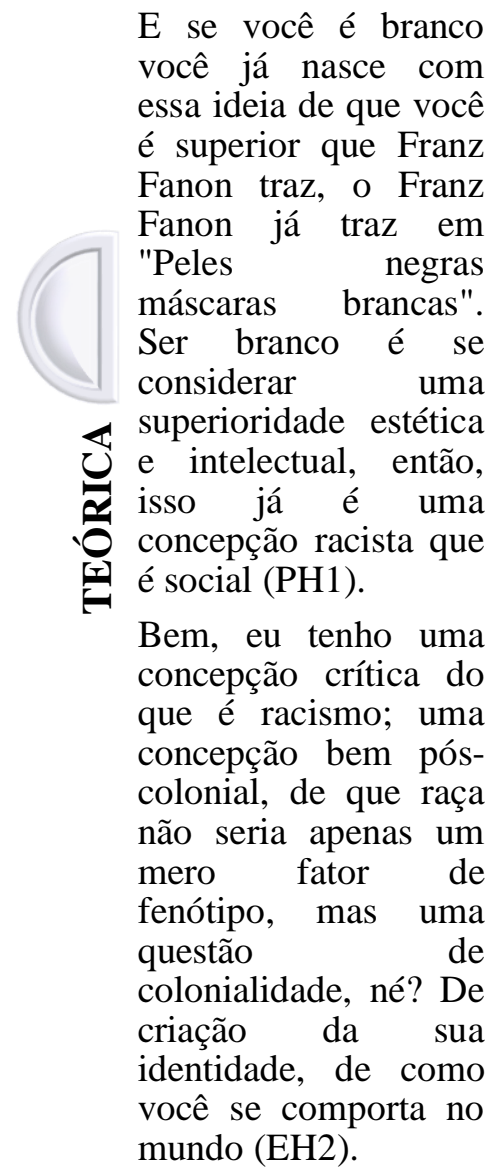

\begin{abstract}
Em tese até nós professores que estudamos isso, você não tá... preparado para essa surpresa, porque o racismo é uma surpresa, então, por mais que você esteja preparado, te pega totalmente indefeso. É... o racismo tem tantas facetas que por mais que você esteja preparado... PH1).
\end{abstract}

$\mathrm{O}$ racismo aqui no Brasil, não todo mundo, mas uma coisa que você vê mais de perto, uma coisa que a gente não vivenciava tão próximo assim lá em Guiné Bissau (EL4).
Mesmo que eu não seja racionalizada como negra o racismo destrói nossos mundos, destrói nossas amigas negras, [...] cria um cenário de dor, digamos assim, dor não tem realização de um cenário possível para o ser humano. Impera mais a morte $\varangle$ que a vida, então para $\bigcup$ mim é isso, racismo é um sistema, não uma ideologia só, não uma opção só (PH2).

Tive terrível experiência com o racismo por toda a minha infância. Eu branca, loira, minha mãe negra, por diversas vezes foi perguntada, quando saíamos juntas, de quem eu era filha, pois pela cor da pele dela as pessoas sempre a associavam ao papel de babá (EP1).

De maneira sintética, as teóricas se relacionam à compreensão do fenômeno do racismo a partir de discussões teóricas, leituras, formações, etc.; as práticas, dizem respeito às marcas e experiências vivenciadas pelos próprios sujeitos racializados/epidermizados; as empáticas também se relacionam com as marcas e experiências, mas nesse caso, observadas por quem não as viveu diretamente, mas que a identificam como racismo.

Dentre os três tipos acima descritos, cabe destacar que embora nós tenhamos apontado se os sujeitos se identificam brancos ou negros, vale mencionar que todos se colocam no lugar epistêmico e não apenas no lugar social e, nesse sentido, assumem a postura ético-política de se contrapor a hierarquização estabelecida como nos mostra Bernadino-Costa e Grosfoguel (Ibid., p. 21): 
Opção Decolonial e Práxis Curriculares de Enfrentamento do Racismo: diálogos com sujeitos curriculantes de licenciaturas da Universidade da Integração Internacional da

Central ao projeto político-acadêmico da decolonialidade é o reconhecimento de múltiplas e heterogêneas diferenças coloniais, assim como as múltiplas e heterogêneas reações das populações e dos sujeitos subalternizados à colonialidade do poder. A dominação colonial seria, portanto, o conector entre diversos lugares epistêmicos.

Nesse sentido, a ferida colonial pode ferir o sujeito de diversas formas, seja teórica, prática ou empaticamente, o que destacamos é a reação diante da colonialidade. Tal reação, ou atitude decolonial, fica mais enfática quando os sujeitos apontam as características do racismo como veremos na próxima subseção.

\section{Características do racismo: da dissimulação à morte}

Além dos três tipos de concepções de racismo, pudemos identificar também suas características: a) letal: b) subalternizador; c) dissimulado e; d) mais presente no Brasil do que nos países africanos.

\section{Características do Racismo}

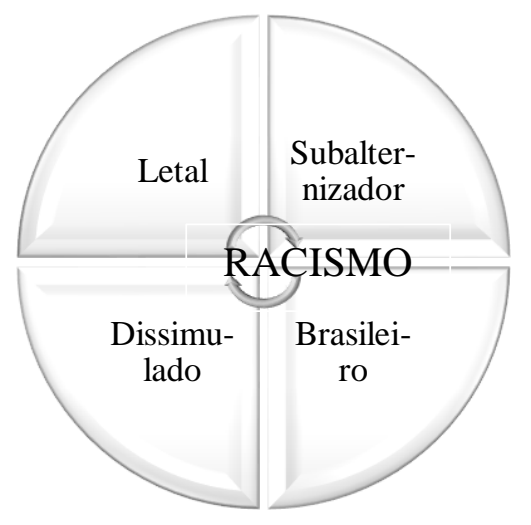

As características identificadas nas falas das pessoas entrevistadas se articulam entre si, como se fossem, de fato, várias partes do mesmo todo. Além da hierarquização racial que por si já subalterniza o lugar epistêmico do ser negro, tanto as estatísticas da violência como as falas das entrevistas comprovam que o racismo mata, como afirma a OS1: "os negros, ainda hoje, sabem que podem ser mortos pelo feitor".

A subalternização e a iminência da morte, que tanto é física como simbólica, se tornam reais por meio da dissimulação e da sua forte presença no Brasil. Estas duas características foram apresentadas de maneiras muito contundentes pelas pessoas entrevistadas, evidenciando que as feridas 
Opção Decolonial e Práxis Curriculares de Enfrentamento do Racismo: diálogos com sujeitos curriculantes de licenciaturas da Universidade da Integração Internacional da Lusofonia Afro-Brasileira coloniais nesta questão são pujantes, variando a intensidade desde a constatação até à denúncia, ao grito. O PP1 denuncia diversas formas em que estas características aparecem e afirma que:

Eu acho que a mais perigosa é aqueles do sorriso, que eles brotam verde, faz um sorriso, mas no cotidiano faz práticas racistas de menosprezar, de desqualificar, seja professor, seja aluno, então, eles estão por aqui, inclusive na instituição que é pensada e foi gestada pensando em parcerias internacionais com países africanos, então, eles estão por aí e nós por aqui combatendo.

Quando o professor fala que os mais perigosos são os que vêm com um sorriso, indica a dissimulação assim como uma fala bem marcante do $\mathrm{PH} 1$ também a respeito da dissimulação do racismo que muitas vezes se esconde por trás de palavras e atitudes como esta:

Eu particularmente não gosto da palavra sofrer, né? A palavra sofrer te coloca em uma posição passiva, eu sofri, aí as pessoas têm pena de você. Não! Enfrentou, sim, nós estamos num lugar onde há conflitos e que na medida do possível acontece que as pessoas enfrentam. Mas também, sobre enfrentamento de racismo que não é nosso caso, as pessoas gostam de ouvir por sadismo, todo negro que vai ser entrevistado por programas de talk show: "fale sobre o episódio de racismo", e, geralmente, o entrevistador é branco e ele gosta de ouvir aquilo por gozo dele.

A dissimulação aqui está agindo em duas frentes. Na primeira coloca o negro como vítima que não reage aos conflitos e tensões a que são submetidos em uma sociedade estruturalmente racista, reforçando a ação da colonialidade. E na segunda alimenta o gozo e sadismo do branco que, se entendendo como "superior" se deleita ao ouvir as lamentações da vítima, denunciando a violência de que trata Fanon (1968). O professor PH1 chama a atenção que esta dissimulação rejeita a palavra enfrentamento, pois ela expressa ação/reação o que desmascara o sujeito colonizador e derruba o pedestal da supremacia branca porque reivindica o pé-de-igualdade na relação entre brancos e negros. Fato que a modernidade/colonialidade criou e não deseja que seja desmascarado, des-coberto.

$E$ há ainda outra forma de dissimulação que é a tentativa de continuar negando, escondendo sua existência: "A UNILAB tem racismo de mais, porque tem gente que não para de falar", esta frase foi citada pelo PP1 quando nos relatou que caminhando em direção à sala de aula, ouviu dois estudantes conversando e um deles afirmava que se não se falasse em racismo, acabaria com o racismo na Instituição. 
Opção Decolonial e Práxis Curriculares de Enfrentamento do Racismo: diálogos com sujeitos curriculantes de licenciaturas da Universidade da Integração Internacional da Lusofonia Afro-Brasileira

Nesse caso percebemos a velha estratégia do sistema-mundo moderno/colonial/patriarcal: esconder a colonialidade para fingir que ela não existe e não romper com os padrões que a constitui. Não se fala em romper com o racismo, superá-lo, mas em silenciá-lo. Nesse sentido, a colonialidade age de tal forma, que estudantes africanas/os afirmam que descobriram o racismo aqui no Brasil, a ES3 afirma que o racismo: "aqui pode chegar às vias de fato. Só não chega porque dizem: 'é estudante da federal e a polícia federal vem atrás de você".

A estudante se diz perplexa com estas formas de racismo, porque afirma que em seu país, Guiné Bissau, há algumas questões entre uma etnia e outra e ela afirma que chegam a usar apelidos pejorativos para designar uma e outra, mas que aqui no Brasil, vai além de xingamentos. A fala da estudante nos revela que o racismo é um problema global com manifestações locais como nos mostra Maldonado-Torres (2007, p. 13)

el capitalismo, el sexismo, el racismo, y la homofobia deben considerarse problemas globales con manifestaciones locales en distintos contextos. Y si los problemas que la colonización creó o ayudó a expandir y cementar son tanto locales como globales (quizás habría que hablar como hacen algunos de lo glocal), entonces las respuestas críticas y alternativas planteadas también tienen que tomar ambos terrenos de acción, lo local y lo global.

Nesse sentido, as/os estudantes nos mostram que reconhecem 0 racismo como problema global, que também se manifesta em seus países. Todavia, percebem que os contextos locais amplificam suas manifestações. No caso do Brasil, a colonialidade teve como aliada o mito da democracia racial que ao negar o racismo adiou as respostas críticas ao seu enfrentamento e superação. Diante disso, a colonialidade continua tendo força em seu intuito de hierarquizar as pessoas a partir desse critério racial como nos mostra outra estudante guineense que começou seus estudos no campus baiano da UNILAB e se transferiu para o do Ceará ao terminar o BHU. A estudante destaca que o racismo não vem apenas por parte de pessoas brancas, mas também de outras pessoas negras, vejamos sua experiência local:

Às vezes, como você vê uma pessoa da mesma cor de pele que você, mas ela vai tentando... tentando te de deixar para baixo, porque tem algumas pessoas baianas, né? Que você vê de pele negra, escura como a nossa... da nossa cor assim, mas só porque nós viemos da África eles tentam marcar uma diferença. Eles são negros sim, mas são negros brasileiros, não são negros africanos, aí eles tentam marcar essa diferença entre a gente (EL3).

O contexto local é mais uma vez mencionado na fala da estudante EH2 que mesmo sendo brasileira percebe esta presença do racismo no Brasil para 
Opção Decolonial e Práxis Curriculares de Enfrentamento do Racismo: diálogos com sujeitos curriculantes de licenciaturas da Universidade da Integração Internacional da Lusofonia Afro-Brasileira com as/os estudantes africanas/os: "Até hoje tem gente que olha os africanos como se fossem alienígenas [...] é o que está acontecendo e muitos preconceitos relacionados a cor deles também, porque são negros, se fossem brancos o tratamento seria totalmente diferente".

Quando questionamos a estudante sobre as razões que ela atribui a este comportamento ela fala sobre as características do município, uma pequena cidade, pacata, onde todos se conhecem, e que com a chegada da universidade o município cresceu, mas o racismo faz com que as/os estudantes africanas/os não sejam bem-vindas/os, pois: "aqui as pessoas associam eles a destruidores, acham que eles, estão fugindo da fome na África, né? Acham que eles vêm para Redenção, porque eles não têm comida" (EH2). Uma lamentável concepção sobre estas/es estudantes que também se estende sobre as/os professoras/es

Um aluno que eu orientei, relatou que entre os estudantes
estavam dizendo que as minhas componentes curriculares, às
vezes, tinham uma carga muito pesada, tinha que ficar lendo,
tinha que ficar estudando, e aí ele falou assim: "não, mas se
ele não fizer isso enquanto professor negro o pessoal não
respeita". Então, eles chegaram a essa conclusão, né? Não
que foi essa minha opção, mas uma das hipóteses para eles foi
essa, então essas leituras das ações raciais que acontece na
instituição está muito presente, né? Então, ainda há trabalhos a
trilhar, não é porque a UNILAB recebe estudantes estrangeiros
que o racismo deixa de existir, mas também, hoje os
estudantes estão muito mais instrumentalizados e encorajados
a falar sobre. Talvez, os primeiros estudantes que chegaram,
os estudantes africanos tinham esse receio, uma país que não
é seu, um continente que não é seu, com que eu vou dialogar?
Como posso me ancorar? Então, hoje com os cursos, com as
formações, com as atividades acadêmicas muitos conseguem
se empoderar e se posicionar (PP1).

O professor relata que os próprios estudantes conseguem enxergar como resistência ações que na verdade fazem parte da prática educativa, como Freire (1996) exortava "ensinar exige rigorosidade metódica", mas se o professor negro é rigoroso "é para ser respeitado", é um atributo a mais para minimizar os efeitos da cor e da racialização. Ao mesmo tempo exige que o damnés/oprimido/colonizado habite os dois lados da fronteira (MIGNOLO, 2015), isto é, este sujeito que é definido externamente ao projeto moderno/colonial, muitas vezes não pode se definir a si próprio ou fazer-se ouvir, e quando o faz, de acordo com o autor, segue os parâmetros coloniais.

Não podemos ignorar que esta é mais uma das marcas da fúria colonial, cristalizar identidades subalternizadas para não abalar a superioridade branca estabelecida. Talvez, por isso, a UNILAB esteja mais suscetível a lidar com estas questões do que outras instituições, pois sua própria existência lhe atribui a missão de colocar o dedo nessas feridas. 
Opção Decolonial e Práxis Curriculares de Enfrentamento do Racismo: diálogos com sujeitos curriculantes de licenciaturas da Universidade da Integração Internacional da

Sujeitos: quem é quem nas tensas relações raciais?

As quatro características mencionadas nos levam ao próximo núcleo de sentido que são os sujeitos. Percebemos que as relações racistas se dão notadamente entre sujeitos, aqueles que praticam e aqueles que enfrentam, mas notamos a dificuldade em distinguir estes papeis.

Quando perguntamos "quem são os racistas?" $45 \%$ das pessoas entrevistadas afirmaram que eram "os brancos", outros $45 \%$ não souberam responder e $10 \%$ afirmaram que "todo mundo era racista". Nestes percentuais consideramos as respostas dadas tanto nos questionários que as/os estudantes responderam, quanto nas entrevistas de estudantes e professoras/es.

Tais dados chamaram nossa atenção, pois por um lado afirmar expressamente que o branco é o racista devido à superioridade atribuída ao seu fenótipo pela própria colonialidade, dicotomiza a relação e não considera suas complexidades, fala do lugar social, mas não considera o lugar epistêmico. Pois, vimos que, contraditoriamente, tanto existe a empatia que reconhece o poder destruidor das hierarquizações raciais, como também, existe a fúria colonial que coloca sujeitos negros na situação ambígua de hospedeiro do opressor (FREIRE, 2005).

Por outro lado, afirmar que todo mundo é racista ou não saber identificar quem o é, pode funcionar como uma licença para que o racismo continue agindo. Todavia, olhando por uma perspectiva mais utópica, pode indicar a necessidade de educar as relações étnico-raciais como um todo. Nesse sentido, classificamos os sujeitos em três categorias:

\section{Praticantes}

Aquelas/es que se valem do privilégio de se aproximarem dos padrões raciais estabelcidos, ainda que estejam no lugar social

subalternizado, para ratificar sua pretensa

superioridade em

relação aos que

estão classificados

racialmente como inferiores.

\section{Enfrentantes}

Aquelas/es que estão no lugar epistêmico dos classificados racialmente como inferiores e diante da necessidade de se defender das atitudes racistas, enfrenta-o cotidianamente.

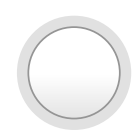

\section{Educandas/os}

Todas/os.

Aquelas/es que devem se submeter a educação das relações étnicoraciais para desconstruir os efeitos da hierarquização racial e promover a horizontalização das relações étnicoraciais 
Opção Decolonial e Práxis Curriculares de Enfrentamento do Racismo: diálogos com sujeitos curriculantes de licenciaturas da Universidade da Integração Internacional da

De acordo com Bernadino-Costa e Grosfoguel (2016), o terceiro grupo de sujeitos estaria próximo do projeto decolonial, pois:

O Brasil, em decorrência dos projetos de ações afirmativas em curso nas universidades públicas do país desde o início desse milênio, depara-se com a possibilidade de incorporar a experiência negra e indígena não apenas na formulação de conhecimento, mas também na busca de soluções para os problemas que enfrentamos. A partir deste locus epistêmico, podemos construir um pensamento decolonial em âmbito nacional, assim como podemos construir um diálogo intercultural com outros sujeitos que vivenciam processos de subordinação no sul global.

Dessa forma, podemos perceber como a UNILAB assume um caráter diferenciado nesse contexto, por ser um locus privilegiado na perspectiva das relações Sul-Sul e promover as mudanças epistêmicas necessárias diante do desafio de promover a educação das relações étnico-raciais, apesar dos desafios expostos nas concepções aqui levantadas.

\section{Considerações Finais}

Como vimos, o racismo é definido pelos sujeitos curriculantes como uma hierarquização fenotípica, seja restrita ou ampliada. Entendemos que tal hierarquização está pautada na classificação racial constituída como um dos pilares do colonialismo, a racialização/epidermização, que classifica e hierarquiza os sujeitos a partir da ideia pseudocientífica de "raça", a qual de acordo com Quijano (1999) agrega critérios como cor, para justificar a exploração negra e naturalizar a ideia de superioridade/inferioridade entre brancos e negros.

Assim, tomando as concepções de racismo analisadas, percebemos uma predisposição a enfrentá-lo, combatê-lo, superá-lo. Aqui está explícito o esforço em direção ao enfrentamento e superação do racismo por meio do estímulo ao desenvolvimento de pesquisas e desenvolvimento de ações que favoreçam tanto a discussão como a elaboração de medidas para o seu enfrentamento. Com o respaldo do PDI, percebemos que a forma de pedagogizar o enfrentamento do racismo é na maioria das vezes Intencional. Ou seja, passa pelo planejamento institucional, está previsto nos PPC, ocupa espaço nas salas de aula, nas pesquisas e também nos projetos de extensão e são reconhecidos tanto por estudantes como pelas/os professoras/es.

Isso nos indica um estado de vigilância que mantem atentas/os docentes e discentes diante do racismo, daí decorre dois níveis de compromisso: a) 
Opção Decolonial e Práxis Curriculares de Enfrentamento do Racismo: diálogos com sujeitos curriculantes de licenciaturas da Universidade da Integração Internacional da Lusofonia Afro-Brasileira

global e; b) pessoal dos quais derivam ações pedagógicas como podemos visualizar abaixo.

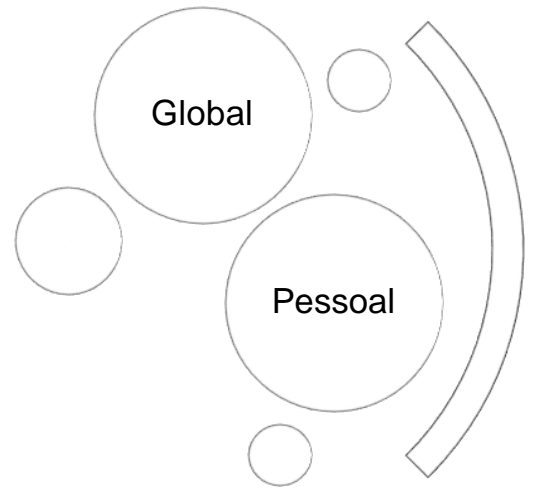

NÍVEIS

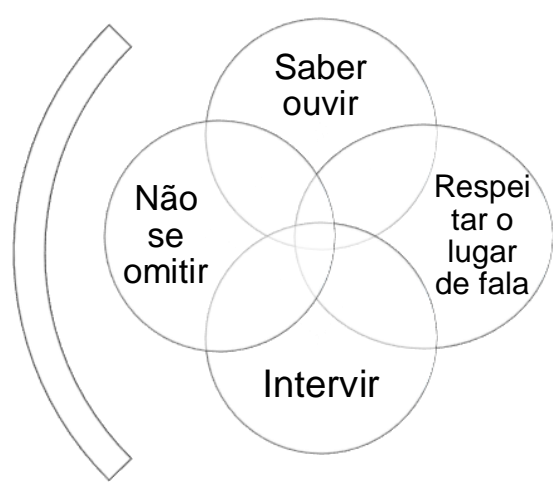

AÇÃO PEDAGÓGICA

Nesse sentido, compreendemos que o compromisso parte de dois níveis, dos quais decorrem ações pedagógicas. Necessariamente, nem todos os sujeitos curriculantes alcançam os dois níveis do compromisso, mas o nível global que é influenciado ao âmbito da política curricular para a educação das relações étnico-raciais imputa ao menos a não omissão diante do tema. Representa quebrar o silenciamento, reconhecer e se posicionar diante da ferida colonial.

Nesse sentido, para compreendermos como se materializa cada nível do compromisso destacamos duas falas da $\mathrm{PH} 2$ que apontam para este comprometimento com o enfrentamento do racismo. No âmbito do primeiro nível ela nos diz "não tem nem a possibilidade de escolher se blindar fingindo que não vê, entendeu? Colocando uma parede como isto não está acontecendo, não tem essa possibilidade, está como se fosse uma ferida sempre aberta, né?" (PH2). E em outro momento da entrevista ela reforça este compromisso mais global, trazendo-o para uma perspectiva mais pessoal, ao afirmar: "eu não me omito, né? Eu penso que é minha responsabilidade, não é porque eu não seja negra que eu não tenho responsabilidade em relação a luta contra racista, a questão é o que eu vou fazer, eu não vou falar o que tu tens que fazer" (PH2).

No nível global, a professora chama a atenção para o seu compromisso em não fazer de conta que não está vendo o racismo e, ao mesmo tempo, no nível pessoal, entende que não tem o direito de ocupar um lugar de fala para dizer o que o negro tem, ou não, que fazer diante de determinadas questões que implicam em racismo. Inclusive aponta que "nossos colegiados são bem brancos, você pode ser muito empática, mas não é a mesma coisa" (PH2), ratificando que existem papeis distintos na construção da consciência negra, 
Opção Decolonial e Práxis Curriculares de Enfrentamento do Racismo: diálogos com sujeitos curriculantes de licenciaturas da Universidade da Integração Internacional da Lusofonia Afro-Brasileira como discutimos no quarto capítulo. O segundo nível, decorre da sensibilização dos sujeitos curriculantes seja teórica, prática ou empaticamente e leva a ações pedagogicamente orientadas para o enfrentamento do racismo.

Dessa forma, enfrentar o racismo não é um trabalho individual, mas coletivo, no qual são envolvidos na construção da transformação da colonialidade. Nesse processo de transformação não cabe ao branco dizer o que é consciência negra sob o risco de reforçar estereótipos e não contribuir efetivamente para a superação do racismo. Nesse sentido, as ações voltadas para a tal transformação não estão dadas.

Esta é uma atitude que está respaldada nas exigências que Freire (1996) aponta sobre a necessidade de "saber escutar", mais do que falar, escutar para ponderar que ação pedagógica é adequada para intervir. A disponibilidade em saber escutar representa, estar atento, não se fazer de rogado enquanto a colonialidade e o racismo dissimulam sua presença e atuação.

Percebemos que saber ouvir, respeitar o lugar de fala e não se omitir constituem uma prática pedagógica antirracista, pautada nas concepções de racismo que, nesse caso, as/os docentes carregam como saberes para sua prática profissional, a fim de comprometer-se com a sua superação.

\section{Referências}

AGAR, Michael. The Professional Stranger: An Informal Introduction to Ethnography, New York: Academic Press, 1996.

ALMEIDA, Eliene Amorim de. A interculturalidade no currículo da formação de professoras e professores indígenas no Programa de educação intercultural da UFPE/CAA - Curso de Licenciatura Intercultural. Tese (Doutorado) - Universidade Federal de Pernambuco, CE. Programa de Pós-graduação em Educação, 2017.

BARDIN, Laurence. Análise de Conteúdo. São Paulo: Edições 70, 2011. BERNARDINO-COSTA, Joaze; GROSFOGUEL, Ramón. Decolonialidade e Perspectiva Negra. Revista Sociedade e Estado, Brasília, v. 31, n. 1, p. 15-24, Janeiro/Abril 2016.

DIÓGENES, Camila Gomes; AGUIAR, José Reginaldo (Org.). Universidade da Integração Internacional da Lusofonia Afro-Brasileira UNILAB: Caminhos e Desafios Acadêmicos da Cooperação Sul-Sul. Redenção: UNILAB, 2013.

DUSSEL, Enrique. 1492 El encubrimiento del outro: hacia el origen del "mito de la Modernidad". La Paz: Plural Editores, 1994.

ESCOBAR, Arturo. Mundos y conocimientos de otro modo: El programa de investigación de modernidad/colonialidad latinoamericano. Tabula Rasa. Bogotá Colombia, No.1: 51-86, enero-diciembre de 2003. 
Opção Decolonial e Práxis Curriculares de Enfrentamento do Racismo: diálogos com sujeitos curriculantes de licenciaturas da Universidade da Integração Internacional da Lusofonia Afro-Brasileira

FANON, Frantz. Os condenados da terra. Rio de Janeiro: Civilização Brasileira, 1968.

FANON, Franz. Pele negra, máscaras brancas. Salvador: EDUFBA, 2008.

FERREIRA, Michele Guerreiro; SILVA, Janssen Felipe da. Brasil/África: unidos pelo atlântico, separados pelo currículo escolar? In: PEREIRA, José Alan da Silva; COSTA, Fátima Batista da (Org.). Saberes Múltiplos. Recife: Editora Universitária/UFPE, 2015, p. 79-102.

FERREIRA, Michele Guerreiro. Educação das relações étnico-raciais e prática curricular de enfrentamento do racismo na UNILAB. Tese (Doutorado) - Universidade Federal de Pernambuco, CE. Programa de Pós-graduação em Educação, 2018.

FERREIRA, Michele Guerreiro; SILVA, Janssen Felipe da. Confluências entre Pedagogia Decolonial e Educação das Relações Étnico-Raciais: elementos de uma praxis curricular outra a partir das contribuições de Franz Fanon e Paulo Freire. In. GARCIA, Maria de Fátima; SILVA, José Antonio Novaes da (Org.). Africanidades, afrobrasilidades e processo (des)colonizador: contribuições à implementação da Lei 10.639/03. João Pessoa: Editora UFPB, 2018, 74-113.

FREIRE, Paulo. Pedagogia da Autonomia: saberes necessários à prática educativa. 22. ed. Rio de Janeiro: Paz e Terra, 1996.

FREIRE, Paulo. Pedagogia do Oprimido. Rio de Janeiro: Paz e Terra, 2005.

GROSFOGUEL, Ramón. Para descolonizar os estudos de economia política e os estudos pós-coloniais: Transmodernidade, pensamento de fronteira e colonialidade global. Revista Crítica de Ciências Sociais, v. 80, p. 115-147, março 2008.

GROSFOGUEL, Ramon. A estrutura do conhecimento nas universidades ocidentalizadas: racismo/sexismo epistêmico e os quatro genocídios/epistemicídio do longo século XVI. Revista Sociedade e Estado, Brasília, v. 31, n. 1, p. 25-49, Janeiro/Abril 2016.

GUBER, Rosana. La etnografía, método, campo y reflexividad. Bogotá: Grupo Editorial, Norma, 2001.

MACEDO, Roberto Sidnei. Atos de currículo e autonomia pedagógica: o socioconstrutivismo curricular em perspectiva. Petrópolis, RJ: Vozes, 2013.

MALDONADO-TORRES, Nelson. Del mito de la democracia racial a la descolonización del poder, del ser, y del conocer. [Partes de este ensayo fueron presentadas en la] Conferencia internacional "Reparaciones y descolonización del conocimiento", en Salvador, Brazil, el 25 y 26 de mayo del 2007.

MALDONADO-TORRES, Nelson. Transdisciplinaridade e decolonialidade. Revista Sociedade e Estado, Brasília, v. 31, n. 1, p. 75-97, Janeiro/Abril 2016.

MIGNOLO, Walter. Cambiando las Éticas y las Políticas del Conocimiento: La Lógica de la Colonialidad y la Postcolonialidad Imperial. 2005. Disponível em: www.tristestopicos.org. 
Opção Decolonial e Práxis Curriculares de Enfrentamento do Racismo: diálogos com sujeitos curriculantes de licenciaturas da Universidade da Integração Internacional da

MIGNOLO, Walter. Historias Locales/Diseños Globales: Colonialidad, Lusofonia Afro-Brasileira conocimientos subalternos y pensamiento fronterizo. $1^{\underline{a}}$ reimpresión. Madrid: Akal, 2011.

MIGNOLO, Walter. Habitar la frontera. Sentir y pensar la descolonialidad (antología, 1999-2004). Barcelona: CIDOB y UACI, 2015.

QUIJANO, Aníbal. ¡Que tal raza! (Tema central). En: Ecuador Debate. Etnicidades e identificaciones, Quito: CAAP, (no. 48, diciembre 1999): pp. 141-152.

QUIJANO, Anibal. Colonialidade do Poder, Eurocentrismo e América Latina. In:

LANDER, E. (Org.). A Colonialidade do Saber: Eurocentrismo e Ciências Sociais.

Trad. Júlio César Casarin Barroso Silva. 3. ed. Buenos Aires: CLACSO, 2005, p. 227278.

QUIJANO, Anibal. Colonialidad del Poder y Clasificación Social. In: CASTRO-GÓMEZ, S.; GROSFOGUEL, R. (Org.). El Giro Decolonial: Reflexiones para una diversidad epistémica más allá del capitalismo global. Bogotá: Siglo del Hombre Editores; Universidad Central, Instituto de Estudios Sociales Contemporáneos y Pontificia Universidad Javeriana, Instituto Pensar, 2007, p. 93-126.

VALA, Jorge. A análise de Conteúdo. In: SILVA, A. S.; PINTO, J. M. (Org.).

Metodologia das Ciências Sociais. 4. ed. Porto: Edições Afrontamento, 1990, pp. 101-128.

WALSH, Catherine. Interculturalidad, Plurinacionalidad y Decolonialidad: Las Insurgencias Político-Epistémicas de Refundar el Estado. Tabula Rasa. Bogotá, Colombia, No.9: 131-152, julio-diciembre 2008.

WALSH, Catherine. Interculturalidad crítica y educación intercultural. In: VIAÑA, J.; TAPIA, L.; WALSH, C. Construyendo Interculturalidad Crítica. 3. ed. La Paz, Bolivia: CAB Instituto Internacional de Integración del Convenio Andrés Bello, 2010, pp. 75-97. 